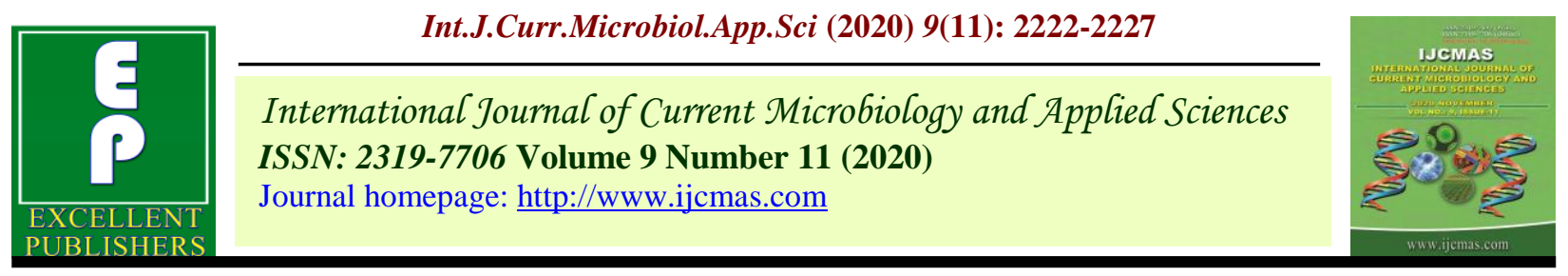

Original Research Article

https://doi.org/10.20546/ijcmas.2020.911.266

\title{
Growth and Productivity of Wheat as Influenced by Crop Residue Incorporation under Rice-wheat, Guar-wheat and Cotton-wheat Cropping Systems
}

\author{
Gurjinder Singh and Balwinder Singh Dhillon * \\ College of Agriculture, Guru Kashi University, Talwandi Sabo, Punjab, India \\ *Corresponding author
}

\section{A B S T R A C T}

\begin{tabular}{|l|}
\hline Ke y w o r d s \\
$\begin{array}{l}\text { Crop residue, Guar, } \\
\text { spike length, Straw } \\
\text { and wheat }\end{array}$ \\
\hline Article Info \\
$\begin{array}{l}\text { Accepted: } \\
17 \text { October } 2020 \\
\text { Available Online: } \\
10 \text { November } 2020\end{array}$ \\
\hline
\end{tabular}

\section{Introduction}

Conservation agriculture involving zero or minimum-tillage and innovations in crop residue management (CRM) to avoid straw burning should assist in achieving sustainable productivity and allow farmers to reduce nutrient and water inputs, and reduce risk due to climate change. High yields of the irrigated RW system have resulted in production of huge quantities of crop residues (CRs). Crop residues generally left over plant parts of crops after harvest and threshing are important natural resources. The crop residue recycling helps in converting the surplus farm waste into useful products to meet the nutrient requirements of crops apart from improving the ecological balance of crops production system, but burning of rice straw is common in north-western parts of India causing nutrient losses, and serious air quality problems affecting human health and safety. About $82 \%$ of rice residue produced is burnt in the field after harvesting rice by combine harvester, resulting in the substantial loss of plant nutrient there in. Singh et al., (1996) reported beneficial effect of rice straw on wheat yield incorporated 3 weeks before sowing of wheat in clay loam soil. Several studies also revealed that incorporation for crop residue improved not only physical, chemical and biological properties of soil but 
also increased wheat yield over burning in the long term experiments. The burning of crop residue and continuous use of chemical fertilizer may cause environment pollution.

Long-term studies of the residue recycling have indicated improvements in physical, chemical and biological health of soil. In intensive cropping system timely agricultural operations are key factors to get maximum returns. The farmers are, therefore, gradually shifting from traditional methods to mechanized farming.

Rice-wheat system has considerable significance to India's food self-sufficiency and food security, but due to intensive application of chemical fertilizer and excessive use of pesticides and irrigation water, the quality of soil health and quality of water become deteriorated day by day which lead to the reduction of crop productivity.

To avoid this problem farmers resort to burning of crop residues, which not only lead to loss of huge biomass but also cause environmental pollution. Farmers in northwest India dispose a large part of rice straw by burning in situ. A large portion of the residues, about 140 million tonnes, is burned in field primarily to clear the field from straw and stubble after the harvest of the preceding crop. The problem is severe in irrigated agriculture, particularly in the mechanized rice-wheat system.

The main reasons for burning crop residues in field include unavailability of labour, high cost in removing the residues and use of combines in rice-wheat cropping system especially in the Indo-Gangetic plains (IGP). So there is a need to adopt ways and means to manage these valuable resources. Incorporation of crop residues alters the soil environment, which in turn influences the microbial population and activity in the soil and subsequent nutrient transformations. It is through this chain of events that management of crop residues regulates the efficiency with which fertilizer, water, and other reserves are used in a cropping system.

\section{Materials and Methods}

The present investigation was carried out in an experimental area of research farm of Guru Kashi University, Talwandi Sabo (Bathinda) during Kharif and Rabi season in the year 2018-20. Talwandi Sabo is located at $29^{\circ}$ $57^{\prime} \mathrm{N}$ latitude and $75^{\circ} 7$ ' E longitude and altitude of 213 meters above the sea levels. This tract is characterized by semi humid climate, where both winters and summers are extreme.

The experiment was laid out in randomize block design with three replications. The crop residue of previous harvested crop was incorporated in the same plot before sowing of next crop in Rice Wheat, Cotton-Wheat and Guar-Wheat cropping system. Total number of plots was 36 and the plot size was $6 \mathrm{~m} \mathrm{x} 4 \mathrm{~m}$.

The experimental data analyzed using Analysis of Variance technique in randomized block design. The LSD at 0.05 per cent of probability were calculated for testing the significance of difference between any two means where, ' $F$ ' test was significant.

\section{Results and Discussion}

\section{Growth parameters of wheat}

\section{Plant height}

At harvesting stage, the maximum plant height of wheat crop was obtained with treatment $\mathrm{T}_{9}(103.25 \mathrm{~cm})$ followed by treatment $\mathrm{T}_{11}(101.98 \mathrm{~cm})$ and $\mathrm{T}_{10}(100.35$ $\mathrm{cm}$ ) which was statistically at par in 2018-19. 
During 2019-20, at harvesting stage of wheat crop maximum plant height was obtained with treatment $\mathrm{T}_{9}(114.01 \mathrm{~cm})$ which was significantly better than other treatments. The minimum plant height was recorded with treatment $\mathrm{T}_{8}(97.26 \mathrm{~cm})$. The present results are similar to the findings of Meelu et al., (1994) reported that incorporation of rice residue $5.0 \mathrm{t} \mathrm{ha}^{-1}$ with recommended dose of fertilizer had increased the height, number of tillers and yield attributes of wheat.

Table.1 Treatment details

\begin{tabular}{|l|l|l|}
\hline Treatments & Kharif 2018/2019 & Rabi 2018-19/2019-20 \\
\hline $\mathbf{T}_{\mathbf{1}}$ & Wheat straw to rice & Rice straw to wheat \\
\hline $\mathbf{T}_{\mathbf{2}}$ & Wheat straw to rice & No Rice straw to wheat \\
\hline $\mathbf{T}_{\mathbf{3}}$ & No wheat straw to rice & Rice straw to wheat \\
\hline $\mathbf{T}_{\mathbf{4}}$ & No wheat straw to rice & No Rice straw to wheat \\
\hline $\mathbf{T}_{\mathbf{5}}$ & Wheat straw to cotton & Cotton straw to wheat \\
\hline $\mathbf{T}_{\mathbf{6}}$ & Wheat straw to cotton & No Cotton straw to wheat \\
\hline $\mathbf{T}_{\mathbf{7}}$ & No wheat straw to cotton & Cotton straw to wheat \\
\hline $\mathbf{T}_{\mathbf{8}}$ & No wheat straw to cotton & No Cotton straw to wheat \\
\hline $\mathbf{T}_{\mathbf{9}}$ & Wheat straw to guar & Guar straw to wheat \\
\hline $\mathbf{T}_{\mathbf{1 0}}$ & Wheat straw to guar & No Guar straw to wheat \\
\hline $\mathbf{T}_{\mathbf{1 1}}$ & No wheat straw to guar & Guar straw to wheat \\
\hline $\mathbf{T}_{\mathbf{1 2}}$ & No wheat straw to guar & No Guar straw to wheat \\
\hline
\end{tabular}

Table.2 Effect of crop residue incorporation on plant height and number of effective tillers $\mathrm{m}^{-2}$ of wheat

\begin{tabular}{|c|c|c|c|c|}
\hline Treatment & \multicolumn{2}{|c|}{ Plant height $(\mathbf{c m})$} & \multicolumn{2}{c|}{ Number of effective tillers $\mathbf{~ m}^{-2}$} \\
\hline & $\mathbf{2 0 1 8 - 1 9}$ & $\mathbf{2 0 1 9 - 2 0}$ & $\mathbf{2 0 1 8 - 1 9}$ & $\mathbf{2 0 1 9 - 2 0}$ \\
\hline $\mathbf{T}_{\mathbf{1}}$ & 98.95 & 107.25 & 274.34 & 280.45 \\
\hline $\mathbf{T}_{\mathbf{2}}$ & 97.23 & 104.45 & 259.16 & 265.45 \\
\hline $\mathbf{T}_{\mathbf{3}}$ & 98.31 & 106.36 & 268.48 & 275.46 \\
\hline $\mathbf{T}_{\mathbf{4}}$ & 94.13 & 103.87 & 252.64 & 259.86 \\
\hline $\mathbf{T}_{\mathbf{5}}$ & 97.29 & 101.78 & 249.36 & 257.46 \\
\hline $\mathbf{T}_{\mathbf{6}}$ & 94.18 & 100.25 & 243.68 & 250.48 \\
\hline $\mathbf{T}_{\mathbf{7}}$ & 95.17 & 101.02 & 247.32 & 253.65 \\
\hline $\mathbf{T}_{\mathbf{8}}$ & 90.39 & 97.26 & 239.78 & 245.98 \\
\hline $\mathbf{T}_{\mathbf{9}}$ & 103.25 & 114.01 & 321.25 & 334 \\
\hline $\mathbf{T}_{\mathbf{1 0}}$ & 100.35 & 109.98 & 287.36 & 298.25 \\
\hline $\mathbf{T}_{\mathbf{1 1}}$ & 101.98 & 112.26 & 301.27 & 331.25 \\
\hline $\mathbf{T}_{\mathbf{1 2}}$ & 99.52 & 109.02 & 278.65 & 290 \\
\hline $\mathbf{L S D}(\mathbf{p}=\mathbf{0 . 0 5}$ & 2.9137 & 1.27 & 3.1 & 3.1 \\
\hline
\end{tabular}


Table.3 Effect of crop residue incorporation on spike length, number of grain spike ${ }^{-1}$ grain yield and straw yield of wheat

\begin{tabular}{|c|c|c|c|c|c|c|c|c|}
\hline \multirow[t]{2}{*}{ Treatment } & \multicolumn{2}{|c|}{ Spike length $(\mathrm{cm})$} & \multicolumn{2}{|c|}{$\begin{array}{c}\text { Number of grain } \\
\text { spike-1 }\end{array}$} & \multicolumn{2}{|c|}{ Grain yield $\left(\mathrm{q} \mathrm{ha}^{-1}\right)$} & \multicolumn{2}{|c|}{ Straw yield (q ha $\left.{ }^{-1}\right)$} \\
\hline & 2018-19 & 2019-20 & 2018-19 & 2019-20 & 2018-19 & 2019-20 & 2018-19 & 2019-20 \\
\hline $\mathbf{T}_{1}$ & 11.35 & 14.58 & 44.50 & 58.86 & 53.25 & 55.98 & 76.68 & 82.29 \\
\hline $\mathbf{T}_{2}$ & 10.29 & 13.28 & 39.79 & 52.14 & 51.61 & 53.46 & 73.80 & 78.59 \\
\hline $\mathbf{T}_{\mathbf{3}}$ & 10.98 & 13.98 & 44.42 & 58.09 & 52.46 & 54.86 & 74.49 & 79.55 \\
\hline $\mathbf{T}_{4}$ & 10.31 & 13.02 & 40.93 & 53.75 & 50.08 & 52.14 & 71.11 & 76.12 \\
\hline $\mathbf{T}_{5}$ & 11.00 & 12.96 & 42.82 & 49.26 & 50.59 & 51.84 & 71.33 & 74.65 \\
\hline $\mathbf{T}_{6}$ & 10.16 & 12.24 & 40.48 & 47.56 & 44.65 & 46.15 & 62.96 & 66.92 \\
\hline $\mathbf{T}_{7}$ & 11.29 & 12.46 & 42.23 & 48.10 & 50.34 & 51.74 & 70.47 & 74.51 \\
\hline $\mathbf{T}_{8}$ & 9.98 & 11.78 & 40.77 & 46.32 & 44.84 & 45.82 & 62.78 & 69.65 \\
\hline $\mathbf{T}_{9}$ & 12.20 & 17.78 & 46.67 & 68.36 & 66.48 & 69.45 & 98.39 & 104.18 \\
\hline $\mathbf{T}_{10}$ & 10.21 & 15.98 & 39.29 & 59.12 & 50.77 & 58.86 & 74.64 & 88.88 \\
\hline $\mathbf{T}_{11}$ & 11.48 & 16.42 & 43.93 & 64.28 & 62.38 & 65.36 & 91.07 & 97.39 \\
\hline $\mathbf{T}_{12}$ & 10.17 & 14.92 & 40.53 & 59.42 & 49.56 & 56.18 & 71.87 & 83.15 \\
\hline $\operatorname{LSD}(p=0.05)$ & 0.61 & 0.52 & 0.79 & 1.48 & 1.79 & 2.17 & 3.64 & 2.40 \\
\hline
\end{tabular}

\section{Number of effective tillers $\mathbf{m}^{-2}$}

A perusal of data in Table 1 reveals that during 2018-19 and 2019-20 the maximum numbers of effective tillers $\mathrm{m}^{-2}$ of wheat crop were recorded in treatment $\mathrm{T}_{9}\left(321.25 \mathrm{~m}^{-2}\right.$ and $334.00 \mathrm{~m}^{-2}$ respectively), which were significantly superior to other treatments and minimum observation was 245.98 numbers of effective tillers $\mathrm{m}^{-2}$ in treatment $\mathrm{T}_{8}$. Similarly Verma and Pandey (2013) reported that the various rice residue and nutrient management systems significantly affect to growth and yield attributes.

\section{Yield attributes of wheat}

\section{Spike length $(\mathrm{cm})$}

Critical study data revealed that during 201819, the maximum length of spike was recorded in treatment $\mathrm{T}_{9}(12.20 \mathrm{~cm})$, which was significantly higher than other treatments and minimum length of spike was recorded in treatment $\mathrm{T}_{8}(9.98 \mathrm{~cm})$. In 2019-20, the maximum length of spike of wheat crop was observed in treatment $\mathrm{T}_{9}(17.78 \mathrm{~cm})$, which were significantly superior to other treatments and minimum observation was 11.78 length of spike in treatment $\mathrm{T}_{8}$. The findings are accordance with Sadeghi and Bahrani (2009) reported that increasing crop residue rates $(0$, 500 and $1000 \mathrm{~kg} \mathrm{ha}^{-1}$ ) increased the soil organic carbon as well as number of spike per plant, spike length, grains per spike, grains per plant and 1000-grain weight of wheat.

\section{Number of grains spike $\mathrm{e}^{-1}$}

The Data given in the Table 3 regarding number of grain spike ${ }^{-1}$ revealed that during 2018-19, the maximum number of grain spike $^{-1}$ was recorded in treatment $\mathrm{T}_{9}$ (46.67 grain spike ${ }^{-1}$ ), which was significantly higher than other treatments. However, the minimum number of grain spike ${ }^{-1}$ was recorded in treatment $\mathrm{T}_{2}$ (39.79 grain spike $\left.{ }^{-1}\right)$, which was statistically at par with treatment $\mathrm{T}_{2}$. In 201920 , the maximum number of grain spike ${ }^{-1}$ of wheat crop was observed in treatment $\mathrm{T}_{9}$ 
(68.36 grain spike $\left.{ }^{-1}\right)$, which were significantly superior to other treatments and minimum observation was 46.32 number of grain spike ${ }^{-1}$ was in treatment $T_{8}$. These findings are correlate with Nair et al., (1979) observed that legumes namely soybean, cluster bean, pigeon pea, and groundnut grown as intercrop in maize had positive residual effect on the number of grain spike ${ }^{-1}$, test weight and grain yield of succeeding wheat crop.

\section{Productivity of wheat}

\section{Grain yield (q ha $^{-1}$ )}

A cursory glance over the data presented in Table 3 indicated that during 2018-19, the maximum grain yield was recorded in treatment $\mathrm{T}_{9} \quad\left(66.48 \mathrm{q}\right.$ ha $\left.^{-1}\right)$, which was significantly superior to other treatments. However, the minimum grain yield was recorded in treatment $\mathrm{T}_{6}\left(44.65 \mathrm{q} \mathrm{ha}^{-1}\right)$, which was significantly lowest. In 2019-20, the maximum grain yield of wheat crop was observed in treatment $\mathrm{T}_{9}\left(69.45 \mathrm{q} \mathrm{ha}^{-1}\right)$, which were significantly superior to other treatments. The minimum observation was $45.82 \mathrm{q} \mathrm{ha}^{-1}$ grain yields in treatment $\mathrm{T}_{8}$. These results collaborates the reports of Similarly Kumar et al., (2005) revealed that deep incorporation of rice residue either by disc plough or by mould-board plough proved a better option for effective disposal of rice residue and recorded significantly higher grain yield as well as net returns of wheat.

\section{Straw yield $\left(\mathbf{q}\right.$ ha $\left.^{-1}\right)$}

From a perusal data of both the years (201819 and 2019-20) also it has been observed the significant influences of the treatments on straw yield. However, $\mathrm{T}_{9}$ have been recorded with the highest straw yield (98.39 q ha-1), which was significantly higher than other treatments. The minimum straw yield was recorded in treatment $\mathrm{T}_{8}\left(62.78 \mathrm{q} \mathrm{ha}^{-1}\right)$, which was significantly lowest during 2018-19. In 2019-20, the maximum straw yield of wheat crop was observed in treatment $\mathrm{T}_{9}(104.18 \mathrm{q}$ $\mathrm{ha}^{-1}$ ), which were significantly superior to other treatments. The minimum observation was $66.92 \mathrm{q} \mathrm{ha}^{-1}$ straw yields in treatment $\mathrm{T}_{6}$. Our result correlate with Bakht et al., (2009) reported that incorporation of crop residue significantly increased the grain and straw yields of wheat.

In conclusion the application of wheat and rice crop residue with recommended dose of fertilizers in wheat crop gives better results in term of crop growth and yield. Wheat crop grown after cotton stalk incorporation in soil is also beneficial over control treatment but not much better than guar and rice straw incorporation treatments. As a legume, guar stover incorporation in soil before wheat sown gave much better response in terms of grain yield and improvement in soil fertility.

\section{References}

Bakht, J., Shafi, M., Tariq, J.M. and Shah, Z., (2009), influence of crop residue management, cropping system and $\mathrm{N}$ fertilizer on soil $\mathrm{N}$ and $\mathrm{C}$ dynamics and sustainable wheat (Triticum aestivum L.) production. Soil \& Tillage Research. 104(2): 233-240.

Kumar, S., Pandey, D. S. and Rana, N. S. (2005), economics and yield potential of wheat (Triticum aestivum) as affected by tillage, rice (Oryza sativa) residue and nitrogen management options under rice-wheat system. Indian Journal of Agronomy, 50(2): 102-105.

Meelu, O.P., Singh, B., and Singh, Y., (1994), green manuring for soil productivity improvement. World Soil Resources Reports FAO, Rome, page. 723- 76

Nair, K. P. P., Patel, U. K., Singh, R. P. and Kaushik, M. K., (1979), evaluation of 
legume intercropping in conservation of fertilizer nitrogen in maize culture. Journal of Agricultural Science, 93(1): 189-194.

Singh, R. and Yadav, D. S. (2006), effect of rice (Oryza sativa) residue and nitrogen, on performance of wheat (Triticum aestivum) under rice-wheat cropping system. Indian Journal of Agronomy, 51(4): 247-250.

Verma, N. K. and Pandey, B. K., (2013), effect of Varying Rice Residue Management Practices on Growth and
Yield of Wheat and Soil Organic Carbon in Rice-Wheat Sequence, International Research Journal Publisher: Global Journals Inc. ISSN: 2249-4626.

Sedegni H. and Bahrani M.J., (2009), effects of Crop Residue and Nitrogen Rates on Yield and Yield Components of Two Dryland Wheat (Triticum aestivum L.) Cultivars, Plant Prod. Sci. 12(4): 497-502.

\section{How to cite this article:}

Gurjinder Singh and Balwinder Singh Dhillon. 2020. Growth and Productivity of Wheat as Influenced by Crop Residue Incorporation under Rice-wheat, Guar-wheat and Cotton-wheat Cropping Systems. Int.J.Curr.Microbiol.App.Sci. 9(11): 2222-2227. doi: https://doi.org/10.20546/ijcmas.2020.911.266 